\title{
RECONCEIVING THE CHRONOLOGY OF INCA IMPERIAL EXPANSION
}

\author{
Dennis E Ogburn \\ University of North Carolina at Charlotte, Department of Anthropology, 9201 University City Blvd., Charlotte, North Caro- \\ lina 28223, USA. Email: dogburn@uncc.edu.
}

\begin{abstract}
The basic chronology of Inca imperial expansion in Andean South America derives from historical accounts from the Spanish Colonial era, but several issues with this traditional chronology have arisen in recent decades. Advances in radiocarbon dating and calibration now give us some ability to refine or rebuild the chronology, and guidelines for obtaining the most useful dates are discussed. Dates recently obtained from the site of Chamical in the southern highlands of Ecuador are evaluated according to those guidelines, and they suggest Inca expansion to the north began 1 to 2 decades earlier than allowed in the traditional chronology. The chronology of Inca expansion presented in the Spanish chronicles is called into question by these and other dates, and by a reconsideration of the nature of sources of Inca history utilized by Spanish writers. Evidence suggests a primary Inca form of recording provincial conquests resulted in lists that were ordered geographically. However, those records were interpreted by colonial writers as being chronologically ordered, which led to written histories of Inca expansion that are not consistent with the actual historical sequence of events. As a result, the preferred approach to building a chronology of Inca expansion should be based on ${ }^{14} \mathrm{C}$ dates, with historical sources used to supplement rather than structure the timeline.
\end{abstract}

\section{INTRODUCTION}

The Inca Empire of Andean South America was rather short-lived, as it expanded rapidly out from the capital of Cuzco and endured for about a century until the Spanish conquest, which began with the arrival of Francisco Pizarro in AD 1532. Beyond this general timeframe, precise dating of the sequence of Inca imperial expansion has been a significant challenge both because of the absence of written records produced before the Spanish conquest and because of the low resolution of applicable dating techniques. But for scholars interested in studying the short-term processes of Inca imperial expansion and maintenance, a refined chronology is of interest because it is central to understanding the duration of the imperial occupation of specific provinces and how Inca strategies in those areas may have been tied to conditions or events in the capital or in other provinces as the empire developed.

Given the unlikelihood of discovering a lost document equivalent to a Rosetta Stone for Inca history, we must focus on nonhistorical means for improving the Inca chronology in terms of establishing or adjusting the timing of incorporation of different regions into the empire. At present, radiocarbon dating is the only method that has the potential for providing data of sufficient precision and accuracy. The primary questions for archaeologists are whether 1) we maintain the framework based on historical data and employ ${ }^{14} \mathrm{C}$ dates to refine it, or 2) we give priority to ${ }^{14} \mathrm{C}$ dates and either treat historical information as supplemental, to be interpreted in light of those dates, or create a chronology independent of the historical record. Here, I address those questions, first discussing how we can obtain data suitable for chronology building even though the accuracy and precision of ${ }^{14} \mathrm{C}$ dating present a challenge for the short-lived Inca Empire. Toward that end, I suggest criteria for obtaining and calibrating the most suitable dates for understanding Inca expansion in the provinces. I then present a new set of dates, derived from the Inca site of Chamical in the northern quarter of the empire, which adhere to those criteria. The dates suggest that the Incas expanded into this region 1 or 2 decades earlier than the historical chronology indicates. In light of the dates from Chamical and the series of reported dates that indicate early expansion in the southern part of the Inca realm, I argue we need to reconceive the chronology of Inca expansion based on ${ }^{14} \mathrm{C}$ dates supplemented with a reframed view of historical data. In particular, I find the historical outlines of Inca expansion to be problematic because the Incas gave priority to geographical rather than chronological order in recording lists of provincial conquests pertaining to the major expansion of the empire. This resulted in data that were mismatched with the linear narratives of Inca history that writers sought to create 
during the Spanish Colonial era, i.e. this created fundamental problems with the accounts that have been our principal sources for understanding the chronology of Inca expansion.

\section{HISTORICAL FRAMEWORK OF THE TRADITIONAL CHRONOLOGY}

For decades, scholars have relied on the chronology of Inca expansion proposed by John H Rowe (initially in Rowe 1944, then more fully developed in Rowe 1945). Before those publications, estimates for the creation and duration of the Inca Empire were based on differing interpretations of the myriad inconsistent dates found in the chronicles produced during the Spanish Colonial era. Working with the same set of sources used by previous scholars, Rowe argued that the dates provided in the AD 1586 chronicle of Miguel Cabello Balboa (1945) were the most reasonable and believable of the various dates given for events in Inca history. Given the dearth of other absolute dating methods that could be employed in the Andes at the time, Rowe proposed a chronology of the Inca Empire based on Cabello Balboa's dates for the reigns and conquests of the last several emperors, with the assumption that dates supplied for earlier rulers were not credible. This chronology (referred to here as the "traditional chronology") was based on what Rowe termed the "standard version" (Rowe 1945:272) of Inca history, which he thought most closely reflected the "official history" as sanctioned by the Inca rulers. While acknowledging that the official history was likely to have been manipulated and censored because of politics, Rowe (1945:268) suggested that the order of conquests as passed down in the accounts was likely to be reasonably preserved. In sum, this traditional chronology was significant not only for proposing plausible absolute dates for Inca expansion but for also making a convincing argument for the rapid expansion and short duration of the empire.

The heart of the traditional chronology (Table 1, Figure 1) focuses on 4 phases of Inca imperial expansion and dominance, beginning with the creation of the empire by the Inca leader Pachacuti (Inca Yupanqui) after he assumed rule from his father in AD 1438, and ending with the death of his grandson, Huayna Capac in AD 1525. The final years of the empire were marked by a struggle for succession and did not result in any significant territorial conquests. The end of an independent Inca Empire is marked by Pizarro's capture of the eventual winner of that contest, Atahuallpa, in AD 1532.

Table 1 The traditional chronology based on Cabello Balboa (1945).

\begin{tabular}{ll}
\hline Year (AD) & Events \\
\hline 1438 & Pachacuti deposes his father Viracocha, embarks on campaigns of imperial conquest. \\
1463 & $\begin{array}{l}\text { Pachacuti remains in Cuzco while sons including Topa Inca lead the army on cam- } \\
\text { paigns of expansion. }\end{array}$ \\
1471 & $\begin{array}{l}\text { Topa Inca succeeds Pachacuti, embarks on further campaigns of expansion. } \\
1493\end{array}$ \\
$\begin{array}{l}\text { Topa Inca dies, succeeded by Huayna Capac, who achieved only limited conquests } \\
\text { during his reign. }\end{array}$ \\
1525 & Huayna Capac dies, succeeded by Huascar, whose rule was contested by Atahuallpa. \\
1532 & Pizarro captures Atahuallpa in Cajamarca. \\
\hline
\end{tabular}

Much of the discussion of Inca chronology has centered on the Cuzco region (e.g. Bauer 1992) and the reigns of these later rulers, but the archaeology of imperial expansion outside the Cuzco region requires framing chronology specifically in relation to the dates of incorporation of different provinces or sections of the empire. Many studies of Inca expansion do not directly tackle chronological questions, often relying on accepted standardized dates for different regions, such as the AD 1476 date for the beginning of the Late Horizon of Peru that was proposed by Rowe (1962). Those that give more specific dates for the Inca arrival typically estimate the date by analyzing the historical 


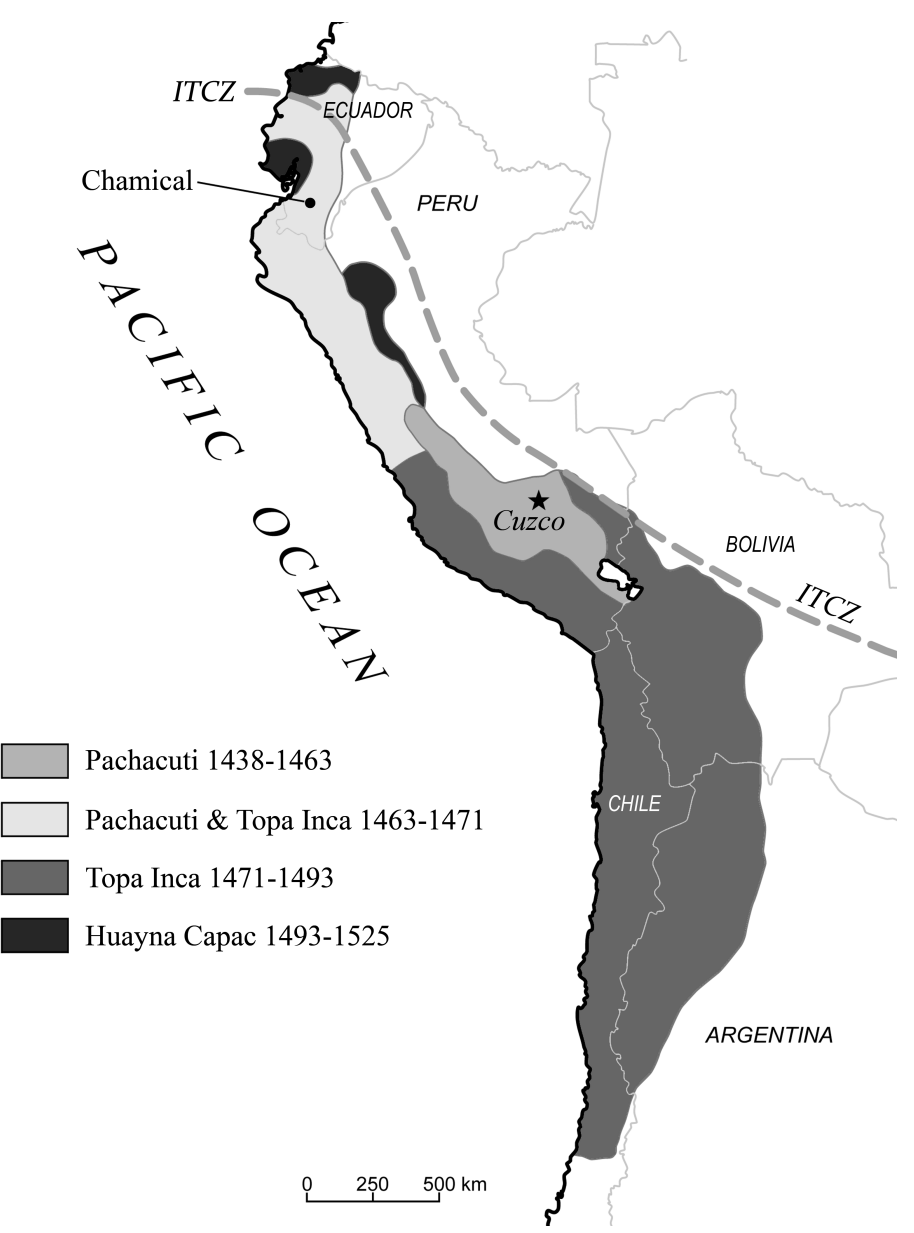

Figure 1 Extent of the Inca Empire along western South America, indicating areas conquered according to the traditional chronology (after Rowe 1945), location of Chamical within the southern highlands of Ecuador, and the average position of the ITCZ along the eastern Andes during the austral summer (according to Mayle et al. 2000).

accounts to determine which Inca ruler is given credit for conquering the region or incorporating it through peaceful submission, then relating that to the traditional chronology (e.g. Menzel 1959; Lippi and Gudiño 2010). The great majority of Inca territory was said to have been incorporated by Topa Inca (Figure 1), both during the rule of his father, Pachacuti, and after the latter's death. So the dates associated with Topa Inca's efforts are particularly important to studying Inca expansion; those include not only the years of his reign but also the year he began to undertake conquests during his father's rule.

\section{RADIOCARBON DATES AND THE CHRONOLOGY OF INCA EXPANSION}

Since the 1940s, researchers have widely employed the traditional chronology (Bauer 1992:38), though in recent times they often note skepticism about the precision of the dates, particularly regarding the earliest phases of expansion. Archaeologists have seldom relied to any significant extent on ${ }^{14} \mathrm{C}$ dates for understanding Inca imperial chronology on the larger scale; nonetheless, numerous dates have been obtained from excavated Inca contexts. Typically, these have not varied 
appreciably from the traditional chronology, and a statistical analysis of combined dates (Adamska and Michczyński 1996) seemed to support the historical dates in general terms.

However, several arguments have been made in favor of refining or remaking the imperial Inca chronology. Bauer (1992:39) argued that because we have no evidence that the Incas or Andean groups recorded the passage of years, we have no way of knowing if Cabello Balboa obtained his dates from an indigenous source or if he invented dates he felt most plausible. While his analysis of available ${ }^{14} \mathrm{C}$ dates from the Cuzco region supported the model of rapid imperial expansion within a few generations, Bauer (1992:46) suggested AD 1400 as a better approximate date for the beginning of the Inca period in the Cuzco region. This is several decades earlier than the traditional date of AD 1438 for the creation of the empire, but it is important to note that Bauer's Inca period specifically marked the appearance of Inca imperial style pottery in the region rather than the expansion of Inca political domination outside the Cuzco heartland. Also, beginning in the 1990s, a series of published ${ }^{14} \mathrm{C}$ dates from Inca contexts in the southern provinces of the empire in Argentina and Chile have led some to argue that Inca expansion in the south may have occurred several decades earlier than believed (e.g. Williams and D'Altroy 1998; Schiappacasse 1999; D'Altroy et al. 2007), opening up the question of how much faith we should put in Cabello Balboa's dates for both the beginning of Inca imperial expansion and the incorporation of the southern provinces. A different argument for producing a chronology independent of historical data was made by Zuidema (1982) based on the theoretical position that Inca history as recorded in the Spanish Colonial era is primarily mythological, reflecting Inca ideological concepts of social structure, religion, time, etc., rather than presenting a linear Western-style historical narrative.

Given these arguments, although there is well-founded skepticism regarding the extent to which ${ }^{14} \mathrm{C}$ dating can refine or remake the chronology of Inca expansion (e.g. McEwan 2008), it is worth further consideration in light of ongoing improvements in methods. Such attempts at improving the chronology could follow 2 paths: 1) Refining the traditional chronology by establishing what are considered better dates for the various waves of imperial expansion as carried out during the reigns of Pachacuti, Topa Inca, and Huayna Capac. Adjustment of dates for the earlier campaigns of expansion could have implications for the timing of subsequent conquests in other regions, the order of which are understood in general outline from historical sources. 2) Establishing a chronology based primarily on ${ }^{14} \mathrm{C}$ dates, obtained from Inca contexts in many different provinces of the empire. This could either be fully independent of the historical record, or employ historical data in a secondary role. This approach would demonstrate the progression of expansion rather than assuming the veracity of the historical sequence of conquests. However, it presents the formidable challenge of obtaining a large number of ${ }^{14} \mathrm{C}$ dates from clearly identified Inca imperial contexts from excavation projects throughout the Inca realm. I will return to these 2 approaches in the discussion below, arguing that there are compelling reasons to follow the second course.

Regardless of the approach favored, certain criteria need to be met to productively improve the chronology of Inca expansion. Obviously, we need to aim for ${ }^{14} \mathrm{C}$ dates of the highest possible accuracy and precision. Of course, the statistical nature of ${ }^{14} \mathrm{C}$ dating will not give us the level of precision to be able to establish the actual order of incorporation of different provinces that may have been conquered within the same decade. But we should be able to discern differences of 30 to $40 \mathrm{yr}$, and under the best circumstances we may be able to discern differences in the range of $20 \mathrm{yr}$ or so. To this end, we should follow the established recommendations for producing the highest quality dates, e.g. $\delta^{13} \mathrm{C}$ corrections should be measured rather than estimated, old-wood problems should be avoided by dating short-lived plant materials such as seeds and annuals, and revising the timing of the Inca conquest in any given province based on multiple rather than single ${ }^{14} \mathrm{C}$ dates. 
Another obvious requirement is sampling from contexts likely to represent the earliest Inca presence in a region. This can be challenging to determine because any individual site or building could have been constructed at any time during the Inca occupation of the area, and the lowest excavated Inca strata will not necessarily date the Inca arrival. Moreover, we do not have a good sense of how long after conquest the Incas began constructing imperial administrative sites, way stations, etc. within a province - it could have been immediate, or after a delay of a decade or more. The best candidates for marking the earliest Inca presence are sites related to the advance of the Inca army, such as forts and other military outposts constructed and utilized during the conquest of a region. These could be relatively rare, however, as the Inca army conquered many provinces quickly and was probably not stationary long enough to require the construction of such facilities in many regions. Furthermore, not all Inca forts were associated with expansion. Many were constructed to defend the borders of the empire, house garrisons, or maintain control over strategic locales over the long term, and would not necessarily mark the arrival of the Incas in an area.

Regardless of the site type, it is vital that samples for dating come from securely established contexts related to the Inca imperial presence. Ideally, the site sampled would lack a pre-Inca component to avoid the possibility of encountering a mixture of earlier and Inca-era material. Preference should be for contexts within Inca imperial sites rather than local sites containing Inca-related material: local sites could produce problematic dates if Inca-style ceramics initially arrived in a region through exchange prior to conquest.

The final major requirement is determining which calibration curve to apply to any specific set of ${ }^{14} \mathrm{C}$ dates. Dealing with the offset between calibration curves for the Northern and Southern hemispheres may be our biggest challenge because even though the Inca Empire was primarily located within the Southern Hemisphere, it also encompassed land within the Northern Hemisphere, spanning from about $34^{\circ} \mathrm{S}$ to $1^{\circ} \mathrm{N}$. As a result of the offset, during the timeframe of interest ( AD 14001532) dates calibrated with the Northern Hemisphere curve (IntCal09; Reimer et al. 2009) can be between 15-20 yr earlier than those calibrated with the Southern Hemisphere curve (SHCal04; McCormac et al. 2004). Twenty years is a significant difference for a relatively short-lived phenomenon like the Inca Empire, and inconsistent application of the different calibration curves could lead to chronological confusion. Clearly, the geographical spread of the Inca realm means that a single calibration curve is not going to be appropriate for all parts of the empire, but no consensus has emerged on how to deal with this situation.

The issue of choosing a curve is complex because the air masses in the 2 hemispheres have different concentrations of ${ }^{14} \mathrm{C}$. This difference exists because the greater extent of ocean in the Southern Hemisphere leads to a greater exchange of $\mathrm{CO}_{2}$ between ocean and atmosphere compared to the Northern Hemisphere. This produces an offset between calibrated ages, which varies over time rather than staying constant (McCormac et al. 2002). Moreover, the division between the hemispheric air masses is not the Equator, but the Intertropical Convergence Zone (ITCZ), where tradewinds from north and south converge and mix the air masses. The ITCZ is not fixed, but moves seasonally as influenced by the position of the sun and the topography of the landforms it passes over. This complicates choosing the appropriate calibration for ${ }^{14} \mathrm{C}$ dates because in some regions the seasonal movement of the ITCZ brings $\mathrm{CO}_{2}$ from the Northern Hemisphere for part of the year and from the Southern Hemisphere during the other part (McCormac et al. 2004:1088).

This is of direct concern because the seasonal shift of the ITCZ impacts a good portion of the Andes. During the austral winter, the ITCZ lies primarily to the north, several degrees above the Equator. But during austral summer, it exhibits a meridional shift, bending southeast down along the eastern side of the Andes and turning east around Bolivia before heading back north (Figure 1). This brings 
the Northern Hemisphere atmosphere close to the Andes during a good part of the year. The key concern for calibrating ${ }^{14} \mathrm{C}$ dates is the predominant source of air during the growing season, as this affects the uptake of $\mathrm{CO}_{2}$ (and thus ${ }^{14} \mathrm{C}$ ) in plants (McCormac et al. 2004:1088). As Finucane et al. (2007) argue for the Ayacucho region of Peru, due to the southward shift of the ITCZ in the primary growing season, the austral summer, much of the $\mathrm{CO}_{2}$ absorbed by plants should represent the Northern rather than the Southern Hemisphere. During that time of year, easterly winds prevail along the Andes down to $\sim 20^{\circ} \mathrm{S}$ (Garreaud 2009), so the weather systems and the moisture they bring derive from the east, across the ITCZ. South of Bolivia, however, the influx of Northern Hemisphere air is much less significant.

Long-term migration of the austral summer position of the ITCZ is another potential issue (McCormac et al. 2004). For the pre-Columbian Andes, the most recent major change in the ITCZ was a southward shift that occurred around $3000 \mathrm{yr}$ ago (Mayle et al. 2000). But on a finer scale, it appears the ITCZ may have shifted to its southernmost position during the Little Ice Age, from $\sim$ AD 1420 to $1560 / 1640$ (Sachs et al. 2009) and subsequently retreating to its current position. This would have encompassed most, if not all, of the duration of Inca imperial expansion, but not all of Inca territory.

In general terms, because of this seasonal movement of the ITCZ, the IntCal curve may be the most relevant for highland sites from Ecuador down to northern Bolivia. In highland areas in the mid-latitudes from central Bolivia to the south, the SHCal curve may be most appropriate. The coastal regions are subject to different conditions. Coastal desert zones are characterized by winds from the west and south; thus, they are dominated by well-mixed Southern Hemisphere air. The Southern Hemisphere calibration curve should therefore be applied to coastal Chile and Peru. In contrast, the coastal Ecuadorean climate is far wetter and likely subject to the influx of Northern Hemisphere air during austral summer, so the Northern Hemisphere calibration may be more suitable. Given the apparent southward shift of the ITCZ during the Little Ice Age (Sachs et al. 2009), the Northern Hemisphere curve may be most appropriate for the far southern coast of Ecuador, despite its currently having an arid climate similar to the northern coast of Peru.

As a suggested approach to calibration in the different zones, I must point out that this is both tentative and general and that there are various complicating issues that cannot be easily resolved. For one, this is only a basic characterization of the complex climatic dynamics of western South America, and does not deal with the significant regional variability that typifies many areas. For many regions, including the Peruvian and Ecuadorean highlands, the air is going to represent some level of mixture between the Northern and Southern Hemisphere atmospheres, but we currently have no way of gauging the level of mixture. Plus, much of Inca territory lies within transitional areas, such as the Peruvian western slopes near the coast, which fall between climate regimes heavily influenced by the seasonal movement of the ITCZ and those dominated by Southern Hemisphere air masses. Choice of calibration curve in those cases can thus be problematic, and we will need to consider strategies for mixing the calibration curves, which can be done with software such as OxCal (Bronk Ramsey 2009).

Another issue to consider is the nature of the materials dated and whether they were exposed to Northern Hemisphere air while they were growing. In the highlands of Peru and Ecuador, food crops grown during the austral summer certainly were, but some irrigated crops and wild plants growing along water courses could also have been growing during other parts of the year. Also, the Incas moved massive quantities of foods, clothing, and other materials between different climatic zones, which means sometimes we will not know if the same calibration curve can even be applied to all excavated remains within a single Inca site. 
Because we cannot easily quantify all of these potential effects, the best approach may be for archaeologists to publish their dates using the latest versions of both calibration curves. This could help limit any tendency for researchers to pick from the different curves to find the best fit for their data or preconceptions. Then, for matters of interpretation and refining chronology, we may employ the different curves as recommended above, but researchers should describe to the best of their knowledge the reasons why one curve would be more suitable than the other, depending on the individual sample and context.

Finally, the shapes of the calibration curves during the period of interest present an issue. For ${ }^{14} \mathrm{C}$ ages $\sim 525-410 \mathrm{BP}$, the IntCal09 curve is quite favorable: it is relatively straight, producing narrowly focused calibrated dates unaffected by multiple intercepts. Moving outside of that window, calibrated dates have poorer resolution because dips and spikes in the curve produce multiple intercepts, with an especially pronounced effect on those dates that have larger errors. In effect, that curve is best suited for dating objects and associated events between about AD 1415 and 1460. Because of the hemispheric offset, the SHCal04 curve is most optimal for ${ }^{14} \mathrm{C}$ ages between $\sim 575-450 \mathrm{BP}$, applicable to objects or events dating between about AD 1410 and 1470.

The lower limit for good resolution in calibrated dates could be problematic for improving the chronology of Inca expansion if any conquests outside the Cuzco region actually occurred prior to $\sim \mathrm{AD} 1410$; fortunately, there is little to suggest any significant expansion at such an early date. The upper limit restricts the potential for refining the dates for provinces incorporated much later than $\sim 1460-1470$ and also makes it difficult to distinguish events of the early Spanish Colonial era from late Inca imperial times. This impacts dating of expansion during what is thought to be the latter part of Topa Inca's reign, and the entire reign of Huayna Capac seems to fall in this calibration "black hole." However, if Cabello Balboa's dates are not grossly inaccurate and most Inca conquests outside the Cuzco region occurred during the reigns of Pachacuti and Topa Inca, as most historical accounts suggest, then much of Inca imperial expansion would have occurred within the optimal calibration window of AD 1410/15 to AD 1460/70. These limits mean that we can create a chronology of Inca expansion that is based mostly, but not entirely, on ${ }^{14} \mathrm{C}$ dates.

\section{CHAMICAL: THE INCA INCURSION IN THE SOUTHERN HIGHLANDS OF ECUADOR}

For exploring the potential to improve the chronology of Inca expansion, I present a set of $7{ }^{14} \mathrm{C}$ dates from Chamical, a site that appears associated with the arrival of the Incas in the southern highlands of Ecuador. Most historical accounts, including chronicles whose authors gathered most of their evidence from Cuzco sources (e.g. Betanzos 1987; Sarmiento de Gamboa 2007) and others who had first-hand experience in Ecuador (Cabello Balboa 1945; Cieza de León 1985), agree that the southern highlands of Ecuador were conquered by Topa Inca during the reign of Pachacuti. According to the traditional chronology, this would have been sometime between AD 1463 and 1471. This area was populated by a subgroup of Cañaris, who apparently resisted incorporation into the Inca Empire. This resistance could have led to the construction of temporary outposts by the Inca army.

Chamical is a small site situated on a point overlooking the confluence of the Paquishapa and León rivers at $1225 \mathrm{~m}, 14 \mathrm{~km}$ west of the town of Oña. The compound was constructed of fieldstone walls with mud mortar, including a main rectangular compound measuring $56 \times 36 \mathrm{~m}$ and 2 separate smaller rectangular structures. Inca imperial-style ceramics were found distributed on the surface outside the compound walls, which included sherds with polychrome decoration (Figure 2) as well as neck fragments and rope nubbins from aribalo-style vessels. Test excavations conducted within the main compound in 2008 uncovered shallow deposits with few remains, indicating a limited occupation with no evidence of pre-Inca activity. 


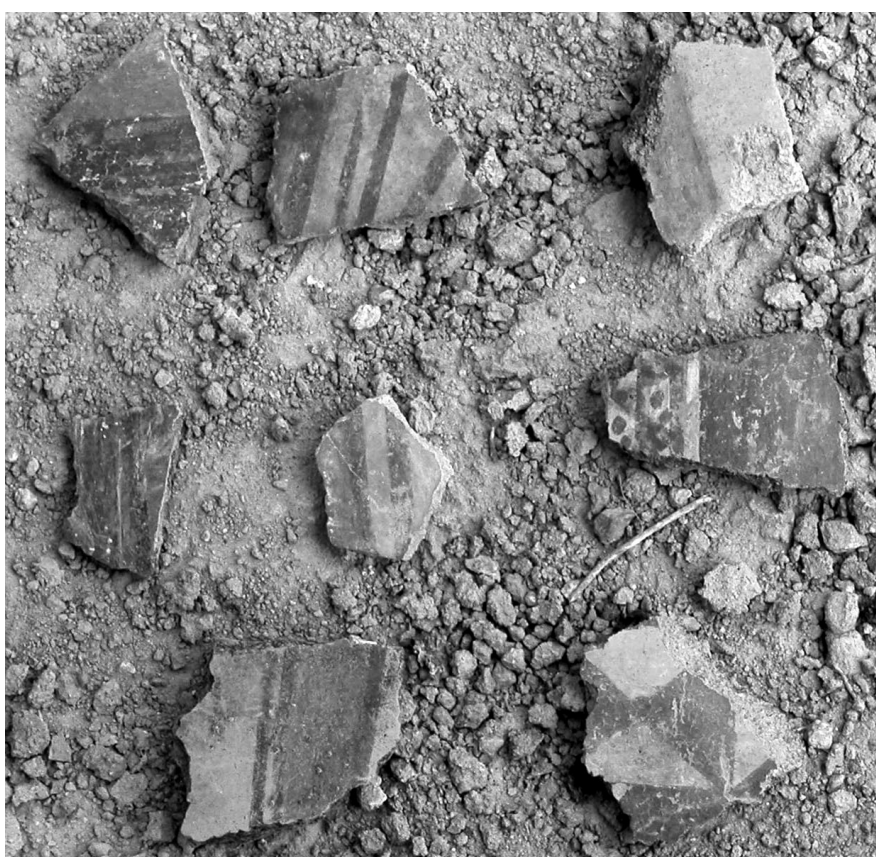

Figure 2 Selection of polychrome Inca ceramics from Chamical; surface collection.

There were no traces of Inca roads leading to the site, making it unlikely that Chamical served as an administrative site. The limited excavation finds included a sling stone and several bone arrow points, suggesting a military focus for Chamical, as does the walled enclosure plan with a single entrance. The limited occupation indicates the site may have been constructed as a short-term outpost, possibly to control or monitor the strategic location at the meeting of 2 major rivers. Thus, if it were constructed during the Inca military advance rather than as a later, internal control point, Chamical could help to establish the date of imperial expansion into the southern sierra of Ecuador.

Seven samples collected during the test excavations (Table 2) were dated by accelerator mass spectrometry (AMS) at the University of Georgia Center for Applied Isotope Studies (lab code UGa), and the dates were calibrated using OxCal v 4.1 (Bronk Ramsey 2009; Table 3). The choice of calibration curve makes a difference of roughly $20 \mathrm{yr}$ in these dates, with the Northern Hemisphere calibration producing dates earlier than the Southern Hemisphere curve. Because Chamical lies within the climatic zone of the highlands that is greatly influenced by the ITCZ, the Northern Hemisphere calibration curve IntCal09 (Reimer et al. 2009) is seen as the most suitable for interpretation of the dates. Two of those calibrated dates (UGa-3459 and UGa-8801) are consistent with the timeframe for the Inca conquest of southern Ecuador according to the traditional chronology (i.e. the AD 14631471 date range derived from Cabello Balboa). One date (UGa-3460) was associated with rubble that blocked the entrance into the compound and appears to represent activity during the early Colonial era. The second most recent date (UGa-8802) falls mostly within late Inca imperial times, suggesting limited use of the site may have continued for several decades.

Of most relevance are the 3 earliest dates, which cluster together and likely represent the construction phase of the site. These included a seed incorporated within the mortar of the enclosure wall (UGa-3458), a fragment from the outermost layer of a wooden post underneath a prepared floor in 
Table 2 Context of ${ }^{14} \mathrm{C}$ samples collected from Chamical.

\begin{tabular}{|c|c|c|c|}
\hline $\mathrm{Lab} \#$ & Sample \# & Material & Context \\
\hline UGa-3457 & Cham-08-01 & Wood & $\begin{array}{l}\text { Fragment from the outermost layer of a post under- } \\
\text { neath a prepared clay floor, Unit 2-B }\end{array}$ \\
\hline UGa-3458 & Cham-08-02 & Seed & $\begin{array}{l}\text { Plant fragments extracted from mortar of the NE enclo- } \\
\text { sure wall }\end{array}$ \\
\hline UGa-3459 & Cham-08-03 & Charcoal & $\begin{array}{l}\text { Burnt cane or reed (roofing material?), from above pre- } \\
\text { pared clay floor, Unit 2-A }\end{array}$ \\
\hline UGa-3460 & Cham-08-04 & Charcoal & $\begin{array}{l}\text { Rubble filling primary entrance into the compound, } \mathrm{N} \\
\text { corner of site, Unit } 4-\mathrm{A}\end{array}$ \\
\hline UGa-8801 & Cham-11-01 & Wood & Fragment of post below prepared floor, Unit 2-C \\
\hline UGa-8802 & Cham-11-02 & Charcoal & Burnt cane or bamboo, above floor, Unit 2-A \\
\hline UGa-8803 & Cham-11-03 & Charcoal & $\begin{array}{l}\text { Piece from an ash layer in the lowest stratum of the site, } \\
\text { Unit A }\end{array}$ \\
\hline
\end{tabular}

Table $3{ }^{14} \mathrm{C}$ dates from Chamical, Ecuador, calibrated with OxCal v 4.1; dates calibrated individually with no prior assumptions, start boundary of phase is derived from Bayesian modeling of the dates as a group (see Figures 3 and 4 ).

\begin{tabular}{|c|c|c|c|c|c|c|}
\hline $\begin{array}{l}\text { Lab \# } \\
\text { (UGa-) }\end{array}$ & $\begin{array}{l}\delta^{13} \mathrm{C} \\
(\%)\end{array}$ & $\begin{array}{l}{ }^{14} \mathrm{C} \text { age } \\
(\mathrm{BP})\end{array}$ & $\begin{array}{l}\text { cal AD } 1 \sigma \\
\text { (IntCal09) }\end{array}$ & $\begin{array}{l}\text { cal AD 2 } \sigma \\
\text { (IntCal09) }\end{array}$ & $\begin{array}{l}\mathrm{cal} \mathrm{AD} 1 \sigma \\
(\mathrm{SHCal04})\end{array}$ & $\begin{array}{l}\text { cal AD 2 } \sigma \\
(\mathrm{SHCal04})\end{array}$ \\
\hline 3457 & -26.1 & $450 \pm 30$ & $1427-1454(68.2 \%)$ & $1414-1480(95.4 \%)$ & $1445-1491(68.2 \%)$ & $\begin{array}{l}1434-1506(82.6 \%) \\
1588-1618(12.6 \%)\end{array}$ \\
\hline 3458 & -11.4 & $450 \pm 25$ & $1431-1451(68.2 \%)$ & $1419-1468(95.4 \%)$ & $1446-1485(68.2 \%)$ & $\begin{array}{l}1439-1502(87.9 \%) \\
1595-1613(7.5 \%)\end{array}$ \\
\hline 3459 & -26.4 & $410 \pm 25$ & $1443-1480(68.2 \%)$ & $\begin{array}{l}1435-1515(87.7 \%) \\
1600-1618(7.7 \%)\end{array}$ & $\begin{array}{l}1460-1501(49.6 \%) \\
1595-1612(18.6 \%)\end{array}$ & $\begin{array}{l}1451-1513(56.6 \%) \\
1545-1624(38.8 \%)\end{array}$ \\
\hline 3460 & -25.2 & $300 \pm 25$ & $\begin{array}{l}1522-1574(50.0 \%) \\
1627-1646(18.2 \%)\end{array}$ & $\begin{array}{l}1495-1602(69.9 \%) \\
1616-1651(25.5 \%)\end{array}$ & $\begin{array}{l}1516-1540(16.5 \%) \\
1625-1660(51.7 \%)\end{array}$ & $\begin{array}{l}1507-1586(35.2 \%) \\
1618-1669(59.0 \%) \\
1787-1793(1.2 \%)\end{array}$ \\
\hline 8801 & -25.5 & $410 \pm 25$ & $1443-1480(68.2 \%)$ & $\begin{array}{l}1435-1515(87.7 \%) \\
1600-1618(7.7 \%)\end{array}$ & $\begin{array}{l}1460-1501(49.6 \%) \\
1595-1612(18.6 \%)\end{array}$ & $\begin{array}{l}1451-1513(56.6 \%) \\
1545-1624(38.8 \%)\end{array}$ \\
\hline 8802 & -25.6 & $380 \pm 25$ & $\begin{array}{l}1452-1498(48.9 \%) \\
1505-1512(5.1 \%) \\
1601-1616(14.2 \%)\end{array}$ & $\begin{array}{l}1446-1523(67.0 \%) \\
1572-1630(28.4 \%)\end{array}$ & $\begin{array}{l}1490-1513(15.6 \%) \\
1547-1623(52.6 \%)\end{array}$ & $1464-1628(95.4 \%)$ \\
\hline 8803 & -23.8 & $440 \pm 25$ & $1433-1456(68.2 \%)$ & $1422-1481(95.4 \%)$ & $1450-1491(68.2 \%)$ & $\begin{array}{l}1443-1505(81.9 \%) \\
1590-1616(13.5 \%)\end{array}$ \\
\hline Start bo & undary & of phase & $1432-1451(68.2 \%)$ & $1412-1457$ (95.4\%) & $1446-1477(68.2 \%)$ & $1416-1495(95.4 \%)$ \\
\hline
\end{tabular}

one room (UGa-3457), and a piece of charcoal from an ash layer in the lowest stratum of the site (UGa-8803). To more precisely gauge the arrival of the Incas in the region from this set of dates, I used the Bayesian analysis (Bronk Ramsey 2009) functions of OxCal (v 4.1) to determine the probable start boundary of the phase of Inca occupation at Chamical. The only assumptions included in the Bayesian modeling were that the main body of 6 dates represented a single occupation phase and that the most recent date (UGa-3460) postdated the Inca occupation. With the IntCal09 calibration (Table 3, Figure 3), the start of the phase falls within the ranges of AD 1432-1451 $(1 \sigma)$ and

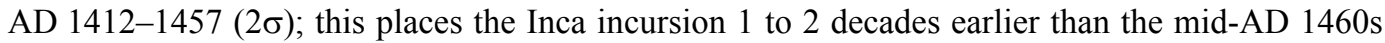
timeframe of the traditional chronology.

As noted above, the choice of calibration curve makes a distinct difference in reading of Inca chronology. In this case, the Southern Hemisphere curve produces broader start boundary ranges of $\mathrm{AD} 1446-1477(1 \sigma)$ and $\mathrm{AD} 1416-1495(2 \sigma)$ (Table 3, Figure 4); the $1 \sigma$ timeframe is consistent 


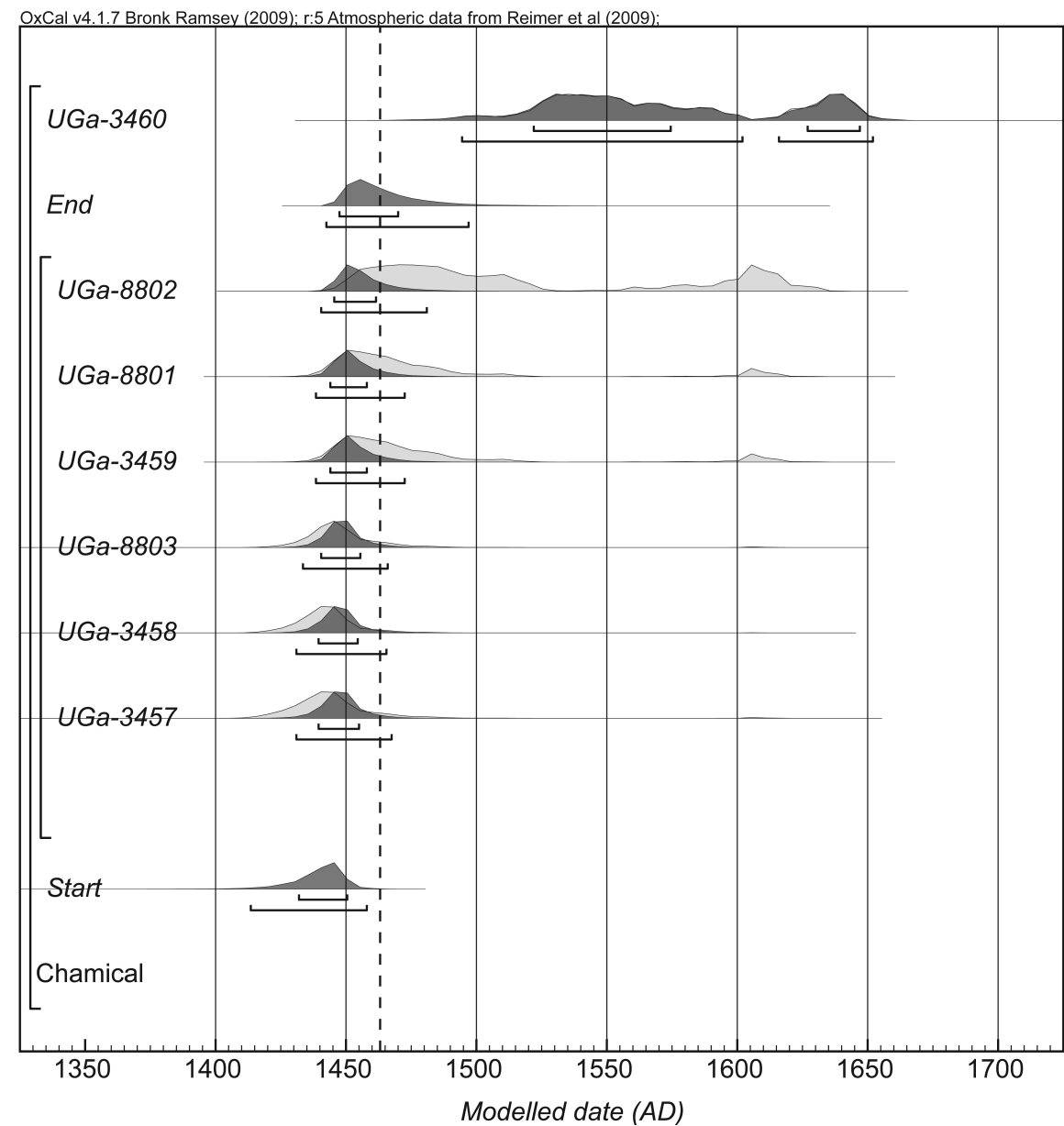

Figure 3 Bayesian analysis of ${ }^{14} \mathrm{C}$ dates for the phase of Inca occupation of Chamical, Ecuador, calibrated with OxCal 4.1 using the IntCal09 curve. Dotted line indicates AD 1463, the date after which the region should have been incorporated into the Inca Empire according to the traditional chronology.

with the traditional chronology, while the $2 \sigma$ timeframe is too broad to be of much use in addressing this question. But given the climatic situation of the southern sierra of Ecuador, it is hard to argue that the $\mathrm{CO}_{2}$ taken in by plants during the growing season was purely derived from the Southern Hemisphere. Furthermore, given the evidence that the ITCZ had shifted further southward during the Little Ice Age (Sachs et al. 2009), it seems most likely that plants in the area received much of their $\mathrm{CO}_{2}$ from Northern Hemisphere air. Thus, exclusive use of the Southern Hemisphere calibration curve cannot be considered appropriate in this case. If we allow that the air in the region during the growing season was more of a mixture from both hemispheres, we could estimate a date that roughly splits the difference between the 2 calibrated ranges, giving us a date range centering on the AD 1450s. Whether we rely on that estimate or entirely on the Northern Hemisphere calibration, the ramifications of the dates from Chamical are that the Incas seem to have expanded into southern Ecuador a decade or more earlier than presumed in the traditional chronology. 


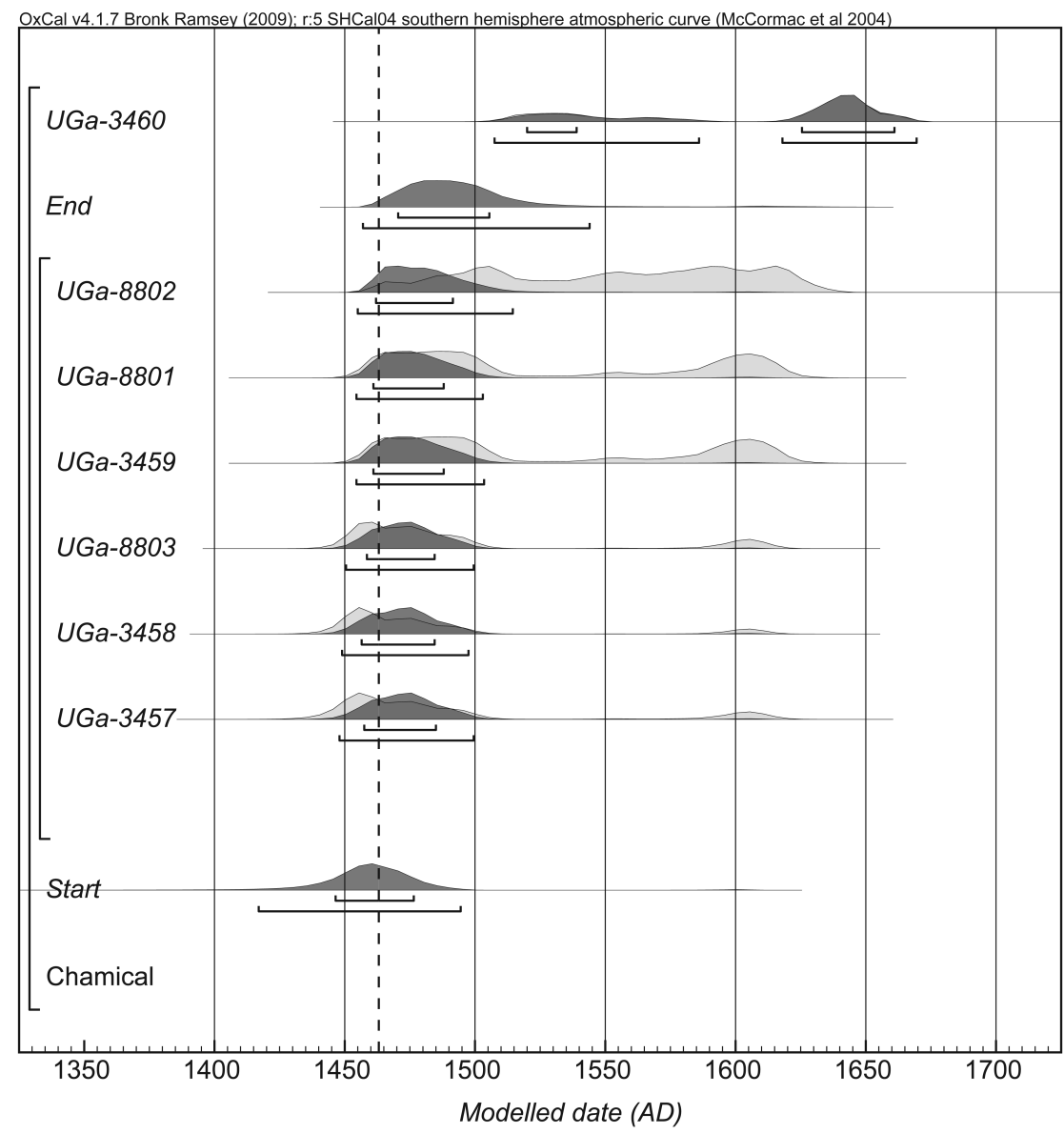

Figure 4 Bayesian analysis of ${ }^{14} \mathrm{C}$ dates for the phase of Inca occupation of Chamical, Ecuador, calibrated with OxCal v 4.1 using the SHCal04 curve. Dotted line indicates AD 1463, the date after which the region should have been incorporated into the Inca Empire according to the traditional chronology.

\section{DISCUSSION: RECONCEIVING THE CHRONOLOGY OF INCA EXPANSION}

Because the dates from Chamical indicate an earlier Inca expansion into southern Ecuador, they point to a need to revise the traditional chronology, but not necessarily to dismiss it entirely. A stronger case for modifying the chronology can be made when also considering the body of early ${ }^{14} \mathrm{C}$ dates from Inca contexts in Argentina and elsewhere in the southern area of the empire (Williams and D'Altroy 1998; Schiappacasse 1999; D'Altroy et al. 2007), which suggest Inca expansion in that area 3 to 6 decades earlier than the timeframe of the traditional chronology. A difference of a few decades is not major in many archaeological contexts. But in terms of Inca expansion and the implementation of imperial strategies of control, that timespan can be quite significant. In particular, it could allow for much greater integration of a region and its people into the Inca state. It also allows for another generation to grow up under imperial control, and provides more time for imperial forms of organization to become embedded in local culture. In essence, uncertainty in the length of Inca occupation arising from conflicts in different sources of chronological information can be problematic for the study of Inca imperialism. Thus, it is imperative to develop the most accurate chronology possible with available methods. 
Given that we cannot rely solely on historical sources for chronological data, we must decide on the appropriate approach for integrating ${ }^{14} \mathrm{C}$ dates with historical information to improve the chronology of Inca expansion. Possible approaches to that problem vary depending on how much credence is given to details of recorded Inca history, which is a challenging question because the historicity of the chronicles and other sources treating the Inca Empire has been subject to much debate (e.g. Zuidema 1964; Julien 2000). On one hand, Inca historical narratives were clearly subject to a variety of alterations because of the passage of time before being written down, translation and filtering through differing languages and cultures, manipulation by competing Inca factions, and alteration to fit differing agendas of Spanish writers, among other things. On the other hand, recorded stories derived from oral Inca histories can at times preserve events in accurate detail (Ogburn 2004). Thus, the historical record can neither be accepted uncritically nor dismissed outright. In the end, we are faced with the choice between the 2 primary approaches to refining the chronology of Inca expansion stated in the introduction: 1) maintaining the framework based on historical data and employing ${ }^{14} \mathrm{C}$ dates to refine it; or 2) giving priority to ${ }^{14} \mathrm{C}$ dates and either treating historical information as supplemental, to be interpreted in light of those dates, or creating a chronology entirely independent of the historical record. As discussed below, an argument can be made for the first option, but it is problematic and there are instead compelling reasons to abandon the traditional chronology in favor of one based primarily on ${ }^{14} \mathrm{C}$ dates.

\section{Refining the Traditional Chronology with Radiocarbon Dates}

Refining the traditional chronology would entail maintaining the basic outline of imperial expansion, i.e. adhering to the sequence of territories incorporated by the different emperors as outlined by Cabello Balboa and other chroniclers (represented in basic form in Figure 1). Modifying the chronology would focus on adjusting Cabello Balboa's dates for the primary stages of Inca expansion based on ${ }^{14} \mathrm{C}$ dates from the provinces in combination with analysis of data from other historical sources. For example, taking into account the dates from Chamical, the entire wave of expansion led by Topa Inca and his brothers should have begun approximately 10 to $20 \mathrm{yr}$ earlier than the AD 1463 date provided by Cabello Balboa. Pushing this stage of expansion back in time suggests the need to reassess the AD 1438 date for the commencement of imperial conquests led by Pachacuti outside of the Cuzco region. Whether that should be pushed back 1 or 2 decades or even more is hard to estimate without new data from the field.

A need for this type of adjustment to the traditional chronology is not surprising. Acceptance of Cabello Balboa's dates as the best approximation was a prudent approach at a time when there was no method for deriving more accurate dates, as Rowe (1945:265) noted. But we have the long-standing issue of not knowing how Cabello Balboa obtained his dates. We do not know the identity of possible indigenous sources (Rowe 1945:277) or whether Cabello Balboa simply arrived at his own best estimates (Bauer 1992:39). While those dates were certainly the most "plausible" ones available from the historical record, plausibility alone does not ensure high accuracy. As Rowe (1946: 274) and others (e.g. Bauer 1992:36-7) have pointed out, while the Incas noted the passing of the seasons from year to year, they did not appear to keep count of the passage of years. However, more recently Rowe (2008; a posthumous translation of a lecture from 1996) argued that the Incas were in fact interested in recording elapsed time, but used rounded numbers in giving these time intervals. This resulted in "approximations, not precise measures" (Rowe 2008:159) of years in the written accounts. Either way, the chronological data given by Inca informants would have been impacted. For example, ages at death of the different emperors, which were significant chronological markers used by chroniclers like Cabello Balboa, were typically rounded off to the nearest decade. It is also clear that not even the Inca nobility of Cuzco knew the specific ages of emperors, as revealed in the 
reports collected by Viceroy Toledo in the late 16th century (Levillier 1940; Covey 2006). Furthermore, there are a number of issues regarding which rulers were included in Inca king lists, which were constructed subject to the politics of Inca and Spanish interests (Covey 2006); these could also impact chronology building. Therefore, there is little reason to suspect that Cabello Balboa had access to data that were more accurate than those available to other writers.

In refining the traditional chronology, it may not be difficult to find historical data to argue for shifts in Cabello Balboa's dates on the order of 1 or perhaps 2 decades. For example, to accommodate the ${ }^{14} \mathrm{C}$ dates from Chamical, a case can be built to support the conquest of southern Ecuador earlier than indicated by Cabello Balboa. This can be done by drawing on various accounts regarding the Emperor Huayna Capac's place of birth, age, and date of death, as follows: It was widely reported that Huayna Capac was born in the Inca center of Tomebamba in the southern highlands of Ecuador (e.g. Cabello Balboa 1945; Betanzos 1987; Sarmiento de Gamboa 2007). This implies that the area must have been incorporated into the empire sometime prior to his birth, allowing for the passage of a few years for the founding and construction of the Inca city. Huayna Capac died around AD 15251528; while not very precise, this date is probably our most accurate because it was very late in the history of the empire and there are multiple reports of his death that were derived from informants with first-hand knowledge (e.g. Cieza de León 1985; Betanzos 1987). It appears he was somewhere around 70 to $80 \mathrm{yr}$ old, according to various Spanish chroniclers (e.g. Betanzos 1987; Sarmiento de Gamboa 2007) and direct testimony of Inca nobility in the Cuzco area (Levillier 1940). An age of 70 indicates that he would have been born by AD 1455, indicating that Tomebamba must have been conquered somewhat earlier. Interestingly, Rowe (2008) made a similar analysis of Huayna Capac's life according to data provided by Betanzos (1987). He arrived at dates that suggest the ruler was born in AD 1457 or 1458 , and that Topa Inca succeeded as ruler at the same time. In both cases, the estimates of Huayna Capac's birth run counter to the post-AD 1463 date from Cabello Balboa, but are consistent with the AD 1440-1455 range indicated by the ${ }^{14} \mathrm{C}$ dates from Chamical.

Similar arguments can be made for revising the traditional chronology to accommodate new ${ }^{14} \mathrm{C}$ dates that do not fit with Cabello Balboa's dates. In the end, however, this approach is very problematic because it hinges on arguing that specific pieces of information are more accurate than others. Without corroboration from other lines of evidence, this would amount to researchers choosing the historical facts they deem most accurate in the attempt to refine the traditional Inca chronology or build a new one. As shown by Covey (2006), there is wide inconsistency in the chronological information embedded in the historical sources, which could easily result in a profusion of conflicting chronologies. In a sense, one of the benefits of following Rowe's suggested dates for more than half a century is that we have mostly avoided such a problem. Because it is desirable to continue avoiding that problem, it would be preferable to follow a different course.

\section{Abandoning the Traditional Chronology and Giving Priority to Radiocarbon Dates}

The need for a different approach to refining the chronology of Inca expansion is made even stronger by the body of early ${ }^{14} \mathrm{C}$ dates from Inca contexts in Argentina and elsewhere in the southern area of the empire (e.g. Williams and D'Altroy 1998; Schiappacasse 1999; D'Altroy et al. 2007). Fully assessing the implications of all of those dates will require evaluating them individually in terms of the criteria outlined above. However, even a basic review of the dates as calibrated with the SHCal04 curve strongly suggests Inca incorporation of at least some southern provinces sometime between AD 1410 and 1440. This is a significant deviation from the post-AD 1471 timeframe of the traditional chronology and points to a sequence of provincial expansion out of line with that described in most accounts. 
The conflict between those ${ }^{14} \mathrm{C}$ dates and the traditional chronology cannot be easily explained by drawing from other historical information, and indicates a clear need to reconsider both the nature of Inca history (D'Altroy et al. 2007) and the extent to which we can reliably draw from the recorded accounts for our archaeological reconstructions of Inca imperial expansion. This divergence from the historical record does not necessarily mean we need to dismiss the potential for the written accounts to provide any historical information pertinent to chronology. But what is specifically called into question is the accuracy of the general outline of imperial expansion given by Cabello Balboa and other chroniclers, including the sequence of provincial conquests and how those conquests were tied to the reigns and activities of different emperors (as distilled in Figure 1). That sequence of expansion is critical because it underlies our understanding of the chronology of Inca imperial expansion, whether or not we choose to tie it directly to the dates given by Cabello Balboa.

In general, that chronological sequence of provincial conquests has appeared well grounded because the same basic outline of conquests is repeated in what are deemed the most reliable accounts of Inca history, such as those of Betanzos (1987) and Sarmiento de Gamboa (2007). Both of those authors collected information directly from members of the Inca nobility, including many who were alive before the arrival of the Spaniards. In theory, the general agreement in the sequence of Inca expansion in those and other Spanish chronicles should reflect an accurate picture of the relative order of provincial conquests as related by native sources. However, there may be a critical problem with interpreting and using much of those data on the sequence of conquests. In essence, there appears to have been a mismatch between a primary Inca form of record keeping and Spanish forms of historical narrative, which led to a standard history of Inca expansion that is actually more disordered (or imprecise) than inaccurate. Specifically, the order of conquests of Topa Inca and his brothers as recorded by Cabello Balboa and others is unlikely to reflect a strictly chronological sequence of Inca expansion. Understanding the nature of this mismatch is crucial because those particular campaigns of conquest accounted for the vast majority of Inca expansion, and our knowledge of the sequence of those campaigns form the basis of how we relate Inca expansion in different regions to the dates given by Cabello Balboa.

Because this problem is critical to the utility of historical data for understanding the chronology of Inca expansion, it merits some discussion in detail. Central to the problem is how the accounts of Inca history were produced from Inca sources, and Julien's (2000) insights into that process are particularly relevant. As she demonstrated, the Incas preserved their historical information in multiple genres, which were focused on specific subjects such as royal genealogy and life histories of rulers. Colonial writers had to integrate information from multiple Inca genres to create linear narrative histories according to Spanish canons. The main contents of specific Inca historical narratives were not extensively detailed accounts, as they were restricted by the genres in which they were created; specific stories or events related in those accounts tended to be brief. For example, life histories of rulers listed major events in their lives such as important conquests, but they did not list all of the emperor's military campaigns. To form their histories, it appears Spanish writers took as their basis the chronological framework provided by the genealogical genre, and then interwove data from other genres to flesh things out. This approach often resulted in problems of sequencing of events, which are evident when details of different written histories are compared.

The key to understanding the recorded chronological sequence of Inca expansion is the existence of an Inca historical form focused on recording military campaigns, another of the Inca historical genres identified by Julien (2000:19). This historical genre essentially consisted of lists of the provinces and peoples conquered by specific royal Incas, and it appears they were a major source for Spanish chroniclers. We are fortunate to have a document that derives directly from that genre, the 
"Probanza de los Incas nietos de conquistadores," published by Rowe (1985). This document was one of the most important Inca-related texts discovered in the 20th century (Julien 2008), yet it is not widely known among English-speaking Andean archaeologists because it has only been available through Rowe's Spanish-language article. Nonetheless, it merits wider recognition because it provides vital insight into Inca historical practices, politics, and imperial expansion, as well as IncaSpanish relations during the Colonial era.

The "Incas nietos" document included the testimony given to Spanish colonial authorities in AD 1569 by Inca nobility regarding the provinces conquered by the founders of their particular royal kin group: the 3 brothers Topa Inca, Amaro Topa, and Topa Yupanqui. As Rowe (1985:194) noted, this presented the first case where we have direct, voluntary declarations from Inca informants about their own history, remarkable because they were not subject to the literary elaboration of Spanish authors. The features and content of the list of conquests suggest that it had been preserved on a quipu (the Inca method for recording information via knotted strings), which was then read to the Spanish authorities (Rowe 1985:197). Notably, Rowe found a significant correspondence between the list of conquests given by the "Incas nietos" and those listed in the chronicles of Cabello Balboa, Pedro Sarmiento de Gamboa, and Fray Martín de Murúa. This indicated that Colonial writers were drawing on sources of information very similar to the "Incas nietos" record to create their linear narratives of Inca imperial expansion.

Most vital for understanding Inca chronology is how the information in this list was organized. Notably, there is no explicit or implicit indication that the document was meant to record a strictly chronological order of conquests. Instead, the "Incas nietos" listed the conquests of their ancestors in geographical order according to the 4 quarters of the empire, beginning with Chinchaysuyu, then proceeding through Antisuyu, Collasuyu, and Condesuyu. This is the same canonical (Julien 2000: 132) or hierarchical (Pärssinen 1992:75) order the Incas used for listing the 4 imperial quarters in many other contexts, e.g. it replicates the sequence of quarters in the list of ceque shrines in Cuzco (Rowe 1985:197). This standardized format for ordering these data has significant ramifications. Most importantly, because the conquests were grouped in this formalized geographical order and the list lacked chronological references, we have no way of knowing if the conquests in one quarter were conducted before or after those in another quarter.

The structuring of the list of conquests within each quarter is less clear. Pärssinen (1992) argues that the internal order was primarily geographical in this and similar accounts that were presumably based on the same type of quipu records. The sequence of provinces listed by the "Incas nietos" is roughly in order as one travels from Cuzco, which could reflect a standardized geographical list of provinces. However, such a sequence could also logically result from the systematic conquest of contiguous territories as the Inca army moved away from Cuzco. Thus, the sequence within each quarter listed by the "Incas nietos" could be roughly chronological. More significant is the likelihood that the list for each quarter combined conquests resulting from multiple military campaigns. The list was structured as if the conquests of each quarter comprised a single military campaign (Julien 2000: 132), and the "Incas nietos" even noted that the Incas returned to Cuzco at the end of the lists for 2 of the quarters. However, a historical sequence of just 4 major military campaigns by Topa Inca and his brothers, one to each quarter, is highly unlikely. As described in various Colonial accounts, the Incas of this generation conducted multiple campaigns in some of these provinces, which were led by differing combinations of Inca nobles. For example, Sarmiento de Gamboa's (2007) list of the provinces conquered by Topa Inca in Chinchaysuyu parallels those listed by the "Incas nietos," but he described 2 distinctly separate military campaigns: one up to the land of the Cañaris (chapter 44), and a second from Cañari territory north to Quito and then along the coast of Ecuador (chapter 46). 
It is this compilation of multiple campaigns within each quarter that creates another significant chronological problem: even if the military campaigns and resulting conquests were basically ordered in time within each quarter, we have no way of comparing the sequence of campaigns between the different quarters. For example, there could have been a first campaign in Collasuyu, then one in Chinchaysuyu, followed by another in Collasuyu that continued into Antisuyu. The Inca quipu-based records, as structured in this genre, would have listed the conquests in Chinchaysuyu first, followed by Antisuyu, ending with the combined conquests of the 2 campaigns in Collasuyu. Drawing from such a record under the assumption that it was chronological would clearly lead to the creation of a historical sequence of conquests that was far from accurate.

As noted, the correspondence between the list of conquests given by the "Incas nietos" and the chronicles of Sarmiento, Cabello Balboa, and Murúa (Rowe 1985) indicate that the Colonial writers drew from sources organized in this fashion. A similar ordering of provinces conquered by Topa Inca and his brothers is also provided in Betanzos (1987), and Cieza de León (1985) includes similar information but lists the quarters in reverse order. These accounts of Inca conquests vary in their details, suggesting they were not necessarily derived from the same quipu-based account of the "Incas nietos," and some may have been drawing from secondary versions of such accounts. Nonetheless, the consistent grouping of conquests by imperial quarter indicates they were all drawing on sources that were geographically structured, and integrating these data with information derived from different genres of Inca history.

Because this standard form of listing conquests was primarily geographical rather than chronological, Spanish chroniclers would have faced the challenge of fitting these campaigns within their own chronological narrative form. They may have been unaware of the geographical structuring of the data, and assumed a chronological order to the conquests. In that case, the sequence of conquests simply needed to be pinned to certain events in Topa Inca's life history that were derived from other historical genres. The problem of this fusing of Inca historical genres is illustrated by the variability in how Pachacuti's death is placed in relation to campaigns of warfare carried out by Topa Inca and his brothers. For example, Betanzos (1987) and Sarmiento de Gamboa (2007) describe Topa Inca conquering and suppressing rebellions in Antisuyu and Collasuyu after the death of Pachacuti, whereas Cabello Balboa (1945) places Pachacuti's death during Topa Inca's campaigns in those 2 provinces. Notably, the account of the "Incas nietos" made no reference to whether the conquests listed occurred during or after the lifetime of Pachacuti, giving no guidance for meshing data from that list with those from genealogical or other genres.

This challenge of meshing data from different Inca historical genres can be seen in similar issues of sequencing elsewhere in the Colonial accounts (Julien 2000:231). In fact, the chronicler Martín de Murúa (2001) directly acknowledged the existence of conflicts between different native sources. In his history of Peru, he listed the Chinchaysuyu conquests of Topa Inca altogether in a short passage, presented as a single campaign during the reign of Pachacuti. His list closely paralleled that of the "Incas nietos" (Rowe 1985), with a few added details regarding some conquests, and as in the native account, Murúa's ends with noting the defeat of Hahua Chumpi and Nina Chumpi. In a later chapter, he describes these places as being conquered on a separate trip by Topa Inca, but after the death of his father and conquests in the other 3 quarters of the empire. Murúa directly attributed the conflict in chronology to what was said by different sets of native informants and stated "entrambas opiniones se pueden tener, pues no va mucho en que haya sido en un tiempo o en otro" ("one could hold either opinion, as it did not much matter what happened in one time or the other") (Murúa 2001:83). 
In sum, the major implication is that imperial incorporation of the great majority of provincesthose conquered by Pachacuti's sons - did not happen in the general order presented by Cabello Balboa and other chroniclers. Instead, accounts from the Colonial period most likely combined a number of separate campaigns of expansion within each quarter to present them as occurring in a linear fashion, when there had actually been multiple campaigns that alternated between different quarters. The writers may have preserved the internal chronological order of places conquered in each campaign, but not the relative order of campaigns between the different quarters of the empire. Thus, it is quite conceivable that Topa Inca engaged in conquests in Argentina and Chile quite early in his career, and that they were recorded by the Spanish as occurring much later because those campaigns were memorialized by the Incas according to a geographical structure that put conquests in Collasuyu toward the end of the list.

This means that our chronology of Inca expansion can no longer be based on the historical accounts, and we should not be judging ${ }^{14} \mathrm{C}$ dates against the traditional chronology. Instead, we must base our chronology on ${ }^{14} \mathrm{C}$ dates, and evaluate the historical record in relation to them. One option would be to eschew the historical record and create a chronology of Inca expansion based solely on ${ }^{14} \mathrm{C}$ assays of samples collected from a vast range of sites throughout the Andes. However, creating a satisfactory chronology with this approach may be impractical given the time and money required, plus we would not be able to deal with any expansion that occurred after $\sim \mathrm{AD} 1470$ because of the nature of the calibration curves. The more practical approach would be to obtain as many ${ }^{14} \mathrm{C}$ dates as feasible, and try to fill in the blanks in the map by critically analyzing the historical record to ascertain which provinces were conquered together in specific campaigns, similar to the analysis of Pärssinen (1992). It may be difficult to dissect the accounts of conquests of each quarter to reveal separate campaigns, but they may in part be identified by the various combinations of leaders said to be involved in differing series of conquests.

\section{CONCLUSIONS}

The dates given to us by Miguel Cabello Balboa, which served as the basis for the traditional chronology of Inca expansion, have not stood the test of time. The traditional chronology promoted by Rowe $(1944,1945)$ has been instrumental in emphasizing the rapid growth of the Inca state out from the heartland of Cuzco while giving us a conception of the timing of stages of expansion in the absence of applicable absolute dating methods. But refinements in ${ }^{14} \mathrm{C}$ dating and calibration methods, a growing database of dates from diverse parts of the former Inca realm, and a reconsideration of the sources of information used to create accounts of Inca expansion in the Spanish Colonial period together point to a need to take a different approach to Inca imperial chronology.

${ }^{14} \mathrm{C}$ dates will not provide the level of precision we might desire within the short span of the Inca Empire. But they can still provide a level of accuracy that is not possible within the framework of the historical accounts of Inca provincial expansion, which are based to a significant extent on geographically rather than chronologically structured data. Under the best circumstances, we may be able obtain dates of sufficient precision and accuracy to date the Inca incorporation of different provinces within a range of about 2 decades. While not ideal, this may be sufficient in some cases to allow ordering of different campaigns of expansion that were spread out in time. Conversely, it may prevent us from establishing the relative order of campaigns that happened much closer in time than is suggested in the historical accounts.

The criteria presented here for providing the best ${ }^{14} \mathrm{C}$ dates are suggestions that are certainly open to discussion. Archaeologists working on Inca imperial expansion will need to decide what level of precision and accuracy are acceptable or necessary for ${ }^{14} \mathrm{C}$ dates and how specifically to calibrate 
the dates and interpret them. Thus, rebuilding the chronology will not be easy. As one step in that direction, the dates from Chamical are interpreted here as indicating Inca expansion into southern Ecuador sometime in the range of AD 1440-1455. Also, we could add that they expanded into parts of Argentina and Chile sometime prior to AD 1440. If the approach suggested here is followed and more dates are produced and integrated into this incipient framework, it will be fascinating to see how a new chronology of Inca imperial expansion unfolds over time.

\section{ACKNOWLEDGMENTS}

Test excavations at Chamical were supported by a Faculty Research Grant from the University of North Carolina at Charlotte. ${ }^{14} \mathrm{C}$ dates from that project were funded through the same grant as well as the College of Liberal Arts and Sciences and the Department of Anthropology at UNC Charlotte. My thoughts on Inca chronology also benefited from discussion with a number of colleagues, especially Gary Urton, and comments from Donna Lanclos have helped me to refine the manuscript. I also thank the anonymous reviewers for their insightful comments and suggestions, which likewise helped improve the final product.

\section{REFERENCES}

Adamska A, Michczyński A. 1996. Towards radiocarbon chronology of the Inca State. Andes - Boletín de la Misión Arqueológica Andina 1:35-60.

Bauer B. 1992. The Development of the Inca State. Austin: University of Texas Press. 185 p.

Betanzos J. 1987. Suma y narración de los Incas [1551]. Martin Rubio M, transcriber. Madrid: Ediciones Atlas. 317 p. In Spanish.

Bronk Ramsey C. 2009. Bayesian analysis of radiocarbon dates. Radiocarbon 51(1):337-60.

Cabello Balboa M. 1945. Obras, Volume 1 [1586]. Quito: Editorial Ecuatoriana. 451 p. In Spanish.

Cieza de León P. 1985. La crónica del Perú segunda parte (El señorio de los Incas) [1553]. Lima: Pontificia Universidad Católica del Perú Fondo Editorial. 238 p. In Spanish.

Covey RA. 2006. Chronology, succession, and sovereignty: the politics of Inka historiography and its modern interpretation. Comparative Studies in Society and History 48(1):169-99.

D'Altroy T, Williams V, Lorandi AM. 2007. The Inkas in the southlands. In: Burger R, Morris C, Matos R, editors. Variations in the Expression of Inka Power. Washington, DC: Dumbarton Oaks. p 85-133.

Finucane BC, Valdez JE, Pérez Calderon I, Vivanco Pomacanchari C, Valdez LM, O'Connell T. 2007. The end of empire: new radiocarbon dates from the Ayacucho Valley, Peru, and their implications for the collapse of the Wari State. Radiocarbon 49(2):579-92.

Garreaud R. 2009. The Andes climate and weather. $A d-$ vances in Geosciences 7:1-9.

Julien C. 2000. Reading Inca History. Iowa City: University of Iowa Press. 350 p.

Julien C. 2008. Incas nietos de conquistadores (1569). In Pillsbury J., editor. Guide to Documentary Sources for Andean Studies 1530-1900. Volume II. Norman: University of Oklahoma Press. p 311-2.
Levillier R. 1940. Don Francisco de Toledo, supremo organizador del Perú; su vida, su obra (1515-1582). Tomo II. Buenos Aires: Biblioteca del Congreso Argentino. 646 p. In Spanish.

Lippi R, Gudiño A. 2010. Inkas and Yumbos at Palmitopamba in northwestern Ecuador. In: Malpass M, Alconini S, editors. Distant Provinces in the Inka Empire. Iowa City: University of Iowa Press. p 260-78.

Mayle F, Burbridge R, Killeen T. 2000. Millennial-scale dynamics of southern Amazonian rain forests. Science 290(5500):2291-4.

McCormac F, Reimer P, Hogg A, Higham T, Baillie M, Palmer J, Stuiver M. 2002. Calibration of the radiocarbon time scale for the Southern Hemisphere: AD 1850-950. Radiocarbon 44(3):641-51.

McCormac F, Hogg A, Blackwell P, Buck C, Higham T, Reimer P. 2004. SHCal04 Southern Hemisphere calibration, 0-11.0 cal kyr BP. Radiocarbon 46(3):108792.

McEwan G. 2008. The Incas: New Perspectives. Santa Barbara: ABC-CLIO. 269 p.

Menzel D. 1959. The Inca occupation of the south coast of Peru. Southwest Journal of Anthropology 15(2): 125-42.

Murúa M. 2001. Historia general del Perú [1590]. Madrid: Dastin. 571 p. In Spanish.

Ogburn D. 2004. Evidence for long-distance transport of andesite building blocks in the Inca Empire from Cuzco, Peru to Saraguro, Ecuador. Latin American Antiquity 15(4):419-39.

Pärssinen M. 1992. Tawantinsuyu, the Inca State and Its Political Organization. Helsinki: SHS. 462 p.

Reimer PJ, Baillie MGL, Bard E, Bayliss A, Beck JW, Blackwell PG, Bronk Ramsey C, Buck CE, Burr GS, Edwards RL, Friedrich M, Grootes PM, Guilderson TP, Hajdas I, Heaton TJ, Hogg AG, Hughen KA, Kaiser KF, Kromer B, McCormac FG, Manning SW, Re- 
imer RW, Richards DA, Southon JR, Talamo S, Turney CSM, van der Plicht J, Weyhenmeyer CE. 2009. IntCa109 and Marine09 radiocarbon age calibration curves, 0-50,000 years cal BP. Radiocarbon 51(4): 1111-50.

Rowe J. 1944. An Introduction to the Archaeology of Cuzco. Cambridge: Papers of the Peabody Museum of American Archaeology and Ethnology. 69 p.

Rowe J. 1945. Absolute chronology in the Andean area. American Antiquity 10(3):265-84.

Rowe J. 1946. Inca culture at the time of the Spanish conquest. In: Steward J, editor. Handbook of South American Indians. Volume 2. Washington: Smithsonian Institution. p 183-330.

Rowe J. 1962. Stages and periods in archaeological interpretation. Southwest Journal of Anthropology 18(1): 40-54.

Rowe J. 1985. Probanza de los Incas nietos de conquistadores. Histórica IX(2):193-245. In Spanish.

Rowe J. 2008. A question of time: Juan de Betanzos and the narrative of the Incas. Julien C, translator. Nawpa
Pacha: Journal of Andean Archaeology 29:155-62. Sachs J, Sachse D, Smittenberg R, Zhang Z, Battisti D, Golubic S. 2009. Southward movement of the Pacific intertropical convergence zone AD 1400-1850. $\mathrm{Na}$ ture Geoscience 2:519-25.

Sarmiento de Gamboa P. 2007. The History of the Incas [1572]. Bauer B, Smith V, translators. Austin: University of Texas Press. 266 p.

Schiappacasse V. 1999. Cronología del Estado Inca. Estudios Atacameños 18:133-40. In Spanish.

Williams V, D’Altroy T. 1998. El sur del Tawantinsuyu: un dominio selectivamente intensivo. Tawantinsuyu 5: 170-8. In Spanish.

Zuidema RT. 1964. The Ceque System of Cuzco: The Social Organization of the Capital of the Inca. Leiden: EJ Brill. $256 \mathrm{p}$.

Zuidema RT. 1982. Myth and history in ancient Peru. In: Rossi I, editor. The Logic of Culture: Advances in Structural Theory and Methods. South Hadley: JF Bergin. p 150-75. 